J. Clin. Chem. Clin. Biochem.

Vol. 20, 1982, pp. 593-602

\title{
Pteridines in the Assessment of Neoplasia
}

\author{
By $A$. Hausen and $H$. Wachter \\ Institute of Medical Chemistry and Biochemistry, University of Innsbruck, Innsbruck, Austria
}

(Received January 14/June 1, 1982)

Herrn Professior Dr. Richard Stöhr zum 80. Geburtstag gewidmet

Summary: Biological processes which might explain the association of pteridine excretion with proliferation are still unknown. Difficulties in the analysis and the determination of naturally occurring pteridines are described. The best quantitative estimations were achieved when measurement of non-reduced forms was attempted. The performance characteristics of such a method for neopterin by high performance liquid chromatography on reversed phase are given.

Enhanced proliferation and dedifferentiation in cell cultures and organisms is paralleled by excretion of unconjugated pteridines into the medium or urine.

Urinary neopterin in healthy subjects and in patients with benign diseases was only significantly raised in patients with viral diseases.

However, an elevation of urinary neopterin occurred in a wide variety of malignant diseases. In haematologic neoplasias correlations of neopterin values to clinical features, to tumour staging, and to laboratory data were apparent. The clinical utility of neopterin measurement was also demonstrated in patients with gynaecologic tumours, particularly in patients with ovarian carcinoma. In both homogeneous patient groups the neopterin assay may provide an additional aid for prognosis and for monitoring therapy. Comparison of the neopterin assay with already established tumour marker substances at least revealed no inferiority in sensitivity. The present results justify extensive investigations in order to evaluate further the clinical applicability of the neopterin assay.

\section{Pteridine in der Diagnostik von Neoplasien}

Zusammenfassung: Die biologischen Funktionen, die die Korrelation der Pteridinausscheidung mit der Proliferation erklïren können, sind bis jetzt noch unbekannt.

Die analytischen Schwierigkeiten und die Bestimmungsmethoden natürlich vorkommender Pteridine sind beschrieben. Die quantitative Bestimmung gelingt am besten, wenn nur die Messung der nicht reduzierten Formen angestrebt wird. Die Zuverlässigkeitskriterien einer solchen HPLC-Methode für Neopterin an reversed phase sind angegeben.

Bei Untersuchung von gesunden Personen und von Patienten mit benignen Erkrankungen wurden nur bei Patienten mit viralen Infekten signifikant erhöhte Neopterinwerte beobachtet. Dagegen kommen erhöhte Neopterinwerte bei vielen malignen Ėrkrankungen vor. Bei hämatologischen Neoplasien wurden Korrelationen der Neopterinausscheidung zu klinischen Parametern, zur Stadieneinteilung und zu anderen Laborkenngrößen aufgefunden. Die klinische Brauchbarkeit der Neopterinbestimmung wurde ebenfalls bei Patienten mit gynäkologischen Tumoren gezeigt. Bei beiden homogenen Patientengruppen sollte die Neopterinbestimmung im Harn zusätzliche Vorteile zur Prognose und Verlaufskontrolle bringen. Ein Vergleich der Neopterinbestimmung mit anerkannten Tumormarkern zeigt, daß sie mindestens gleich empfindlich ist wie diese. Die vorliegenden Resultate rechtfertigen ausführliche Untersuchungen zur weiteren klinischen Erforschung der diagnostischen Möglichkeiten der Neopterinbestimmung.

\section{Introduction}

\section{Biological functions of unconjugated pteridines}

In contrast to the field of purines, the biological functions of most unconjugated pteridines are unknown, despite their common occurrence in various organisms.
This is probably because the pteridines have been investigated only recently and only by a few laboratories.

The reason for this comparatively late research into their biological role lies certainly in analytical difficulties. In some cases the problems of isolation and characterization 
are caused by the low concentrations of pteridines in biological samples; they are generally present only in trace amounts $(1,2)$. An exception is the relatively high concentrations which are found in the wings of Pteridae butterflies. Other problems result from chemical abnormalities such as photolability, uncommon solubility and lack of melting points.

An excellent review of pteridine chemistry up to 1963 is given by Pfleiderer (2). Interesting and more recent aspects of analysis were described in the reports of the pteridines symposia held at Konstanz in 1973 (3) and at La Jolla, California, in 1978 (4), (5-12).

Pteridines are found as pigments in the skin and eyes of insects, amphibians and fish. The essential metabolic roles of unconjugated pteridines which were known or had been proposed till 1982 are summarized in a review by Rembold (1). Today, the best established function is that of 5,6,7,8-tetrahydrobiopterin which serves as cofactor for a set of enzymes which hydroxylate phenylalanine, tyrosine and tryptophan using molecular oxygen $(13,14)$. A similar enzyme catalyses the conversion of glyceryl ethers to carboxylic acids and glycerol (15). Participation of pteridines in the photosynthetic electron transport of photosynthetic bacteria and chloroplasts of higher plants has been proposed by several authors $(16,17)$. The possibility of a regulatory function of pteridines in melatonin biosynthesis (18) and of an interaction between pteridines and DNA (19) requires more detailed research.

\section{Biosynthesis of the pteridine ring}

Unconjugated pteridines are synthesized de novo by mammals and by other higher animals as reported by Kraut et al. (20) and by Pabst \& Rembold (21). As shown in figure 1, during biosynthesis the pteridine ring arises from the purine ring. GTP (guanosine triphosphate) is converted enzymatically to dihydroneopterin triphosphate. The ability of guanine compounds to serve as precursors of pteridines was investigated in larvae of Drosophila melanogaster by Brenner-Holzach \& Leuthardt (22) and in butterflyspecies by Weygand et al. (23) and by Watt (24). Jones \& Brown presented direct evidence that dihydro: neopterin is formed enzymatically in Escherichia coli from GTP (25). The same synthetic scheme is also established in Comamonas sp. (26), in the bullfrog, Rana catesbeiana (27), in Drosophila melanogäster (28), in the Chinese hamster and the Syrian golden hamster (29).

\section{Biological conversion and degradation of pteridines}

As shown in a reaction scheme by Rembold (30) enzymatic or non-enzymatic modification such as cleavage of the side chain, deamination or oxidation of $7,8=\mathrm{di}-$ hydroneopterin could give rise to naturally occurring pterins such as monapterin, biopterin, sepiapterin, xanthopterin, isoxanthopterin, pterin and lumazines.<smiles>NC1=Nc2c(c3c(ncn3CCOPC3CCCCC3)[nH]c2=O)OC1O</smiles>

Guanosine triphosphate

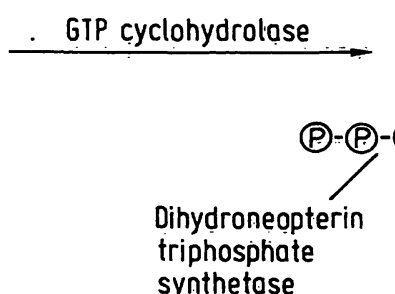

synthetose

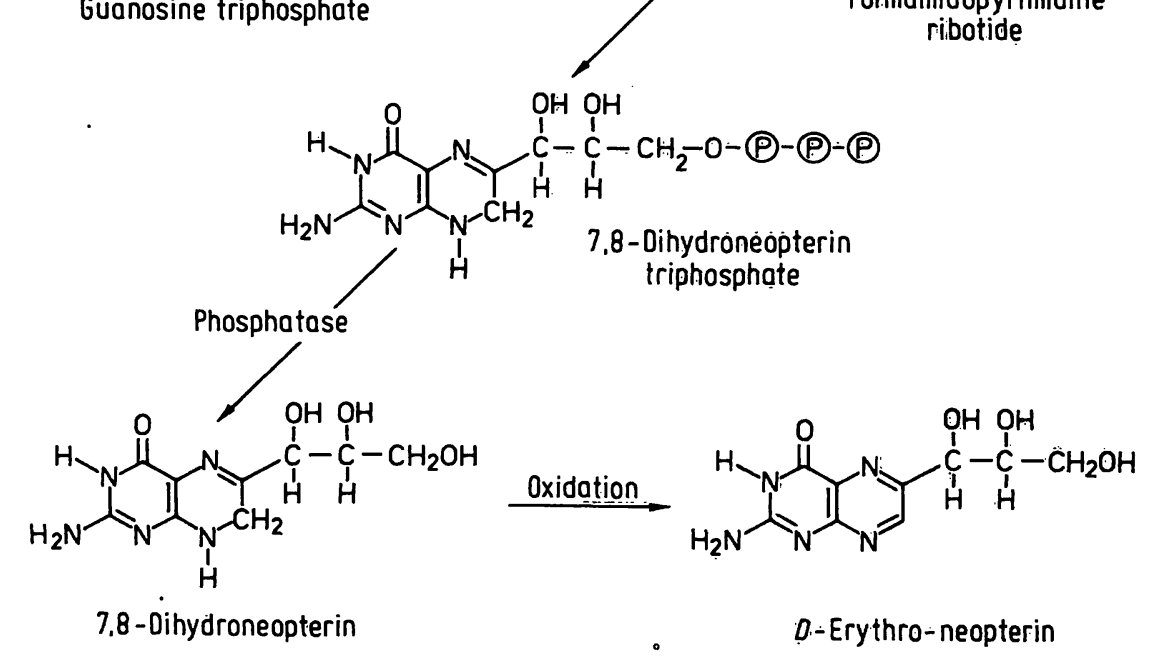

Fig. 1. Biosynthesis of $D$-erythro-neopterin from GTP. 
These are the same reactions that occur in the degradation and thus these pteridines are found as terminal metabolites in culture media of cells and in urine. The different excretion products depend on the presence or absence of specific enzymes. For example, the occurrence of lumazines requires the presence of a pterin deaminase. For most organisms the pteridines represent true terminal catabolites (1).

\section{Analytical Methods for Unconjugated Pteridines}

The diagnostic significance of tumour markers is strongly influenced by the method available for their measurement. As the pteridines occur in extremely small amounts in biological materials the analytical method has to be sensitive, specific and accurate. For clinical laboratory use the practicability of the assay has to be taken into consideration.

A sensitive growth assay using the microorganism Crithidia fasciculata has been reported by Guttman (31). This assay, which is applicable for $L$-biopterin and its reduced forms has been most frequently used, but it is very tedious and time consuming.

In newer methods pteridines are detected by their native fluorescence which generally gives a specific and sensitive determination.

Determination of pteridines by paper chromatography (32) or thin layer chromatography $(33,34)$ does not enable sufficiently accurate quantification. High voltage electrophoretic separation of pteridines (34-36) presents similar problems. The determination of pteridines using isolation techniques on ion exchange materials in a two step separation has been widely applied (37, 38) and adapted for biological fluids. Advances in liquid chromatography have led to the development of high performance liquid chromatographic (HPLC) techniques.

Pteridines have been separated by cation exchange HPLC techniques by different laboratories (39-42). Although sensitivity and specificity is increased compared to the methods cited above, the practicability is diminished by a necessary preliminary purification of the biological material. Practicability and accuracy can be optimized to a great extent by HPLC-analysis on reversed phase. Such assays for the estimation of unconjugated pteridines have been described by several laboratories (42-46). For example the HPLC method on reversed phase was optimized for the urinary neopterin measurement (47): Rapid separation of urine constituents was achieved by an isocratic solvent system on a $10 \mu \mathrm{m}$ reversed phase $C_{18}$ column following a sample preparation through $\mathrm{C}_{18}$ cartridges. Subsequent to elution of neopterin a flow and composition gradient was established in order to accelerate column purification.
Neopterin has been monitored using a spectral fluorescence detector. In order to reduce the effect of physiological variations in urine concentration the neopterin concentration was related to that of creatinine; for this reason it was advantageous that creatinine could be estimated simultaneously with a spectral absorption detector (48). As shown in table 1, this method provides good performance characteristics and is easy to handle. The assay was modified by using a guard column (49), thus enabling automation for routine clinical laboratory use. A gas chromatography-mass fragmentography method (50) seems particularly suited as a reference method. As it is difficult to analyse many samples during one day this accurate assay is not useful for routine laboratories. A radioimmunoassay for biopterin (51) represents an attractive alternative if the HPLC equipment is not already at hand. Thus an $L$-ery thro-biopterin specific assay is applicable to body fluids and tissues.

Tab. 1. Performance characteristics of the urinary neopterin determination by HPLC on reversed phase. Neopterin levels werè measured simultaneously with creatinine levels and related to these.*)

*) Data from Hausen et al. (47).

Linearity

from $200 \mathrm{nmol} / 1$ neopterin to at least $40 \mu \mathrm{mol} / 1$ regression equation: $y=1.006 x-2.94$; $\mathbf{r}=0.9999$

Sensitivity $\quad 120 \mathrm{nmol} / 1$ neopterin or $120 \mathrm{fmol} /$ injection at a peak/noise ratio of $5: 1$

Precision within run between day

$\begin{array}{lcccccc}\text { Sample } & 1 & 2 & 3 & 1 & 2 & 3 \\ \text { n } & 20 & 24 & 24 & 15 & 15 & 15 \\ \text { CV \% } & 6.5 & 3.8 & 3.8 & 7.4 & 2.8 & 7.1\end{array}$

Accuracy mean value of $99.3 \%$ recovery with 6 spiked urinary samples.

Specificity tested through fluorescence spectra for standard and eluted urinary sample following HPLC separation.

Practicability analysis of one sample requires 20 minutes; measurement of 60 samples within 24 hours; low cost of reagents.

Measurement of the total amount of reduced and oxidized pteridines after conversion to the fully oxidized state has also been reported $(41,52)$. Since the use of test substances showed a recovery of $80-90 \%$, quantification of reduced forms using this technique does not yet seem possible with the desired precision and accuracy.

The optimized analytical techniques have enabled research into the relationship between pteridines excretion and biological parameters. The present investigations were undertaken to study the behaviour of pteridine excretion in cancer patients. 


\section{Excretion of Pteridines from Cells, Plants and Animals}

Pteridine excretion as indicator of cell proliferation

Various procaryont and eucaryont organisms excrete pteridines during the growth phase (53). E. coli secretes monapterin in the logarithmic growth phase. At the switch to the stationary phase the excretion of monapterin experiences a burst, whereas in the stationary phase $E$. coli hardly releases any pteridines. The slime mould Physarum polycephalum excretes isoxanthopterin and Acetabularia mediterranea pterin-6-carboxylic acid into the medium. In the same manner the rapid growth of Calanchoe tubiflora is paralleled by release of isoxanthopterin, and the germination of potatoes (Solanum tuberosum) by excretion of isoxanthopterin and monapterin into the medium.

\section{Pteridine excretion as indicator of rapid} or malignant proliferation

Association of pteridines with high metabolic activity in dedifferentiating tissues was indicated by Kokolis \& Ziegler (54) and by Kokolis et al. (55). Elevated concentrations of tetrahydrobiopterin were detected in the skin of Triturus species during larval development and in the regeneration blastema of the adult newt after tail amputation. Interestingly, the growth rate of the regeneration bud was strongly inhibited by injection of isoxanthopterin after amputation.

Kokolis et al. (56) compared tetrahydrobiopterin levels in tissues from human squamous cell carcinoma with levels in tissues from rats. In the tumour samples the ratio of tetrahydrobiopterin to riboflavin was much higher than in normal tissue with high metabolic activity. Furthermore, Kokolis \& Ziegler (57) reported that tetrahydrobiopterin levels in the blood of tumour-bearing rats (Ascites $\mathrm{AH}_{\mathbf{1 3 0}}$ and Guerin T-8 tumours) were raised compared with those in healthy rats.

Albrecht and coworkers (58) investigated the biopterin content of several cell lines in human neuroblastoma. They observed markedly higher biopterin levels in adrenergic neuroblastoma, glioblastoma and fibroblastlike cell lines. 6-Hydroxymethyl-pterin was also shown to be excreted into the medium in large amounts by cancer cells (59).

Increased excretion of a fluorescent component was found in the urine of mice bearing. Ehrlich ascites tumour (35). This metabolite was identified as 6-hydroxylumazine which originates during analysis from 7,8-dihydro-6-hydroxylumazine (36). The urinary excretion of this pteridine related to indoxylsulfate (excreted at a constant rate in mice) was determined as $0.65 \pm 0.21$ (mean $\pm \mathrm{SD}$ ) for 110 healthy mice. In contrast, this quotient increased to $2.47 \pm 1.09$ (mean \pm SD) for 120 Ehrlich ascites tumour-bearing mice on the fifth day after tumour transplantation. As shown in figure 2 this quotient increases up to the sixth day and then falls; there is a similar increase in the number of tumour cells. In these animals, tumour proliferation is paralleled by the excretion of 7,8-dihydro-6-hydroxylumazine, which thus acts as an index of tumour growth.

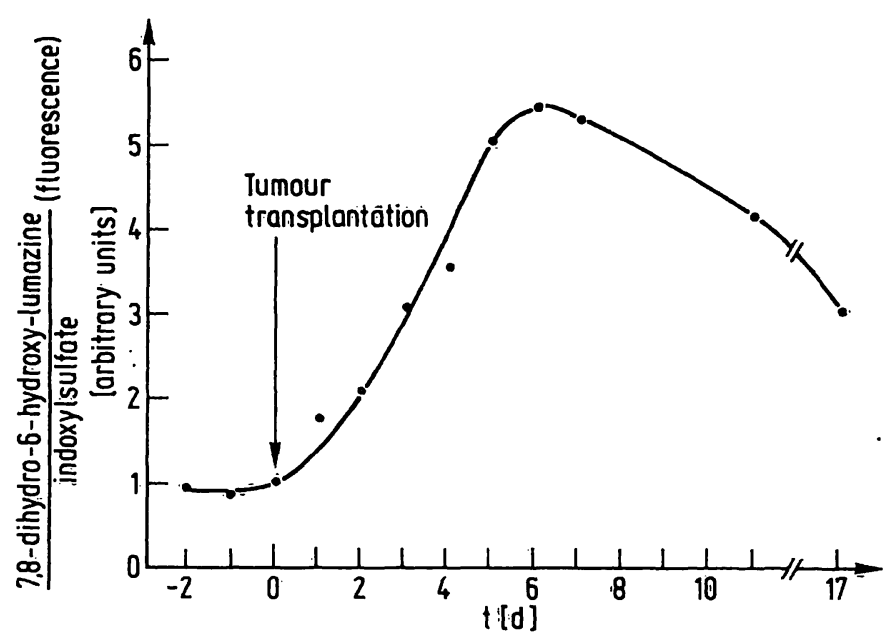

Fig. 2. Urinary levels of 7,8=dihydiro-6-hy droxylumazine in relation to indoxylsulfate (arbitrary fluorescence units) following transplantation of Ehrlich ascites tumour in mice. Each point corresponds to the mean value from 12 mice.

\section{Excretion of Pteridines in Healthy Sübjects}

A pterin present in pupae of bees was identified as 2-amino-4-hydroxy-6(D-erythro-1,2,3-trihydroxypropyl)-pteridine by Rembold \& Buschmann (60), who called it neopterin.

Sakurai \& Goto (38) isolated néopterin from human urinè. Quantitative estimation of urinary neopterin and biopterin was first performed by Fukushima \& Shiota on 4 healthy persons (61). Since these results and those of Fukushima \& Nixon and of Fukushima èt àl. $(52,62)$ ( 3 healthy subjects each) are presented in mg pterin per liter urine, they are not comparable with the data of other authors. The same is true of the urinary biop= terin levels obtained by Leeming and coworkers (63) using the Crithidia fasciculata assay on 60 healthy persons. The quantifications of urinary pteridines related to creatinine, which have so far been published, are summarized in table 2 . With one exception, measurement of the total reduced and nonreduced forms was attempted. Oxidation of pteridines by the available methods is not quantitative (44) and was at first not reproducible $(47,52,62)$. These methodological difficulties explain conflicting results obtained using these methods. However, the new data $(42,64,67,68)$ compare well.

A recent investigation (69) with 417 healthy individuals (208 male, 209 female) showed that at all àges the men had significantly lower mean values than the women $(p<0.01)$. In addition, a correlation between the 
Tab. 2. Comparison of normal values of urinary pteridines obtained from different authors.

a) the total of reduced and non reduced pteridines was determined following oxidation

b) the native neopterin was determined. Pteridine levels in $\mu \mathrm{mol}$ pteridine per mol creatinine

\begin{tabular}{|c|c|c|c|c|c|c|}
\hline References & $\begin{array}{l}\text { Number } \\
\text { of subjects }\end{array}$ & $\begin{array}{l}\text { Pterin } \\
\text { 6-carboxylic- } \\
\text { acid }\end{array}$ & Neopterin & Biopterin & Xanthopterin & $\begin{array}{l}\text { Isoxantho- } \\
\text { pterin }\end{array}$ \\
\hline $\begin{array}{l}\text { a) Röthler \& Karobath (50) } \\
\text { a) Niederwieser et al. (64) } \\
\text { a) Stea et al. (65) } \\
\text { a) Rokos et al. (66) } \\
\text { a) Dhondt et al. (42) } \\
\text { a) Dhondt et al. (67) } \\
\text { a) Nagatsu et al. (51) } \\
\text { a) Nagatsu et ai. (68) }\end{array}$ & $\begin{array}{r}9 \\
7 \\
20 \\
23 \\
12 \\
55 \\
13 \\
13\end{array}$ & $27 \pm 3$ & $\begin{array}{l}223 \pm 74 \\
280 \\
794 \pm 34 \\
221 \pm 81 \\
280 \pm 50 \\
306 \pm 91\end{array}$ & $\begin{array}{r}457 \pm 165 \\
720 \\
1173 \pm 54 \\
283 \pm 101 \\
709 \pm 162 \\
674 \pm 188 \\
893 \pm 96 \\
739 \pm 77\end{array}$ & $\begin{array}{l}679 \pm 49 \\
229 \pm 73\end{array}$ & $120 \pm 25$ \\
\hline b) Wachter et al. (43) & $\begin{array}{l}628 \\
438\end{array}$ & & $\begin{array}{l}125 \pm 52 \\
152 \pm 52\end{array}$ & & & \\
\hline b) Hausen et al. (49) & $\begin{array}{l}208 \% \\
209 \%\end{array}$ & & $\begin{array}{l}115 \pm 36 \\
140 \pm 40\end{array}$ & & & \\
\hline b) Hausen et al. (47) & 60 children & & $163 \pm 65$ & & & \\
\hline
\end{tabular}

neopterin/creatinine ratio and age was demonstrated. Children have notably higher urinary mean neopterin/ creatinine values $(47,67)$. This relationship may result to some extent from the distinct variation of urinary creatinine levels with sex and age.

Since the most useful application of tumour markers at the present time is the monitoring of treatment, the oscillation of the neopterin excretion over a longer time period is of interest. The urinary neopterin levels were determined daily over a one-month period in 4 normal individuals (47). The individual variance coincided with the range found to be typical for people of the same sex and age.

In order to assess neoplasias the upper normal limits of urinary pteridines must be stated. Rokos and coworkers (45) considered values of neopterin above $447 \mu \mathrm{mol} / \mathrm{mol}$ creatinine to be abnormal. However, this limit which was based on the estimation of neopterin and biopterin following an oxidation step prior to analysis by HPLC, did not take into account the sex-and age-dependent variations of urinary neopterin levels $(49,67,69)$.

Recommended upper levels of normal excretion, which do take into account the sex- and age-dependence of urinary neopterin have recently been stated $(49,69)$. Table 3 shows the mean and median values and the upper confidence limits for each sex and age group. These limits, calculated according to Liebermann (70), include with $95 \%$ probability $97.5 \%$ of healthy subjects, thus enabling the accurate interpretation of results.

\section{Excretion of Pteridines in Patients with Benign Diseases}

Measurement of urinary pteridines is of clinical value in the recognition of variants in phenylketonuria patients $(71,42,64)$. Tetrahydrobiopterin serves as cofactor of the monooxygenases phenylalanine-4-hydroxylase, tyrosine-3-hydroxylase and probably tryptophan-5hydroxylase. The classical phenylketonuria is caused by enzyme deficiency; about 1-3\% of the phenylketonuria patients suffer from tetrahydrobiopterin deficiency due to molecular defects grouped in dihydropteridine reductase deficiency and dihydrobiopterin synthetase deficiency. Since different deficiencies require specific treatment early diagnosis is important. Determination of urinary pteridines is considered a useful tool for classification of phenylketonuria patients. High levels of urinary dihydroxanthopterin were found in classical phenylketonuria patients and in variants $(34,72,73)$. In recent reports increased urinary levels of biopterin derivates in dihydropteridine reductase deficiency $(74,64)$, low serum levels of tetrahydrobiopterin and high urinary levels of neopterin in 7,8-dihydrobiopterin synthetase

Tab. 3. Normal urinary neopterin levels ( $\mu \mathrm{mol}$ neopterin per mol creatinine) and upper confidence limits for different sex and age groups obtained from 417 healthy individuals.*)

*) From Hausen et al. (49)

**) Upper limits tested according to Liebermann (70) containing with $95 \%$ probäbility $97.5 \%$ of healthy subjects.

\begin{tabular}{lllll}
\hline Age & Sex & $\begin{array}{l}\text { No of } \\
\text { subjects }\end{array}$ & $\overline{\mathrm{x}} \pm \mathrm{SD}$ & $\begin{array}{l}\text { Limit of } \\
\text { tolerance**) }\end{array}$ \\
\hline $18-25$ & $\circ$ & 42 & $123 \pm 30$ & 195 \\
$26-35$ & $\circ$ & 29 & $101 \pm 33$ & 182 \\
$36-45$ & 8 & 41 & $109 \pm 28$ & 176 \\
$46-55$ & 8 & 32 & $105 \pm 36$ & 197 \\
$56-65$ & $\circ$ & 31 & $119 \pm 39$ & 218 \\
$>65$ & 8 & 33 & $133 \pm 38$ & 229 \\
$18-25$ & 8 & 55 & $128 \pm 33$ & 208 \\
$26-35$ & 8 & 28 & $124 \pm 33$ & 209 \\
$36-45$ & 8 & 31 & $140 \pm 39$ & 239 \\
$46-55$ & 8 & 28 & $147 \pm 32$ & 229 \\
$56-65$ & 8 & 26 & $156 \pm 35$ & 249 \\
$>65$ & 8 & 41 & $151 \pm 40$ & 251 \\
\hline
\end{tabular}


deficiency $(75,64)$ were demonstrated. These data were confirmed by Dhondt and coworkers (67) using age-paired comparisons.

Significantly $(p<0.0001)$ raised neopterin levels occur in patients with viral diseases $(43,66)$. Urinary neopterin levels were affected moderately by benign cell renewal (76). In 5 patients who had undergone surgery (laparotomy) the highest neopterin excretion was observed between the third and the sixth day. On the day of the highest level, the mean neopterin value \pm SD in $\mu \mathrm{mol}$ neopterin per mol creatinine was $233 \pm 40$. In figure 3 a typical change in urinary neopterin levels following laparotomy due to cholelithiasis is depicted.

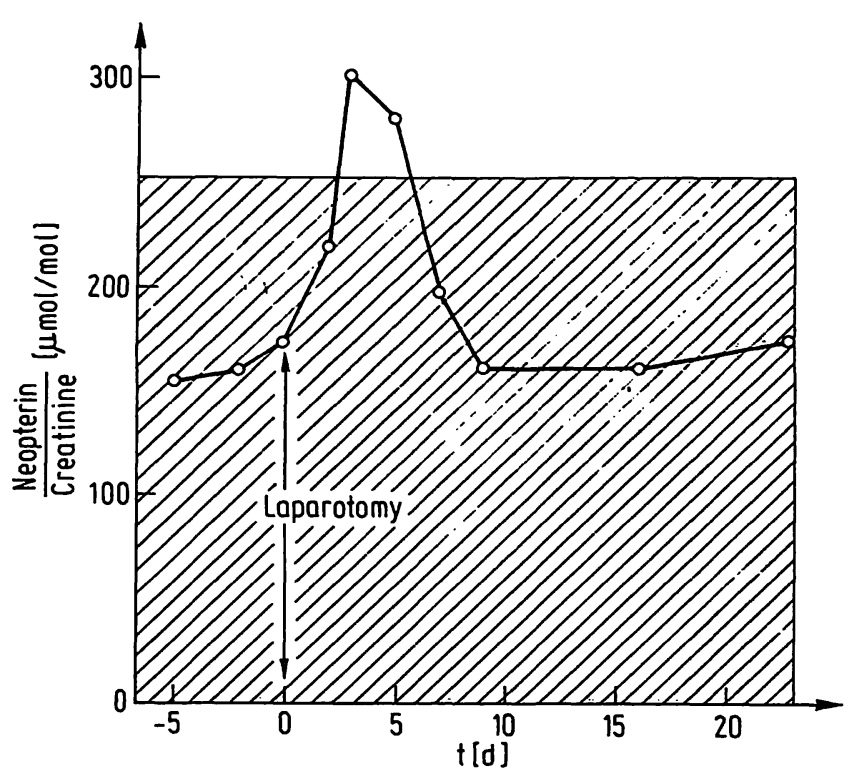

Fig. 3. Urinary neopterin levels following laparotomy due to cholelithiasis. The range below the upper limit for female individuals, age $>65$ years, is hatched.

Slightly increased neopterin levels were observed in patients with hyper-regenerative bone marrow (49). In patients with haemolytic anaemia the mean neopterin value was only a little higher than that of healthy controls. In 5 patients with renal insufficiency coupled with renal anaemia, the mean urinary neopterin level increased nearly to the upper normal limit (45). In 9 patients with renal insufficiency and in 7 patients with psoriasis, mean values above the normal limit were found (66).

\section{Excretion of Pteridines in Patients with Malignant Diseases}

\section{Studies in advanced neoplasias of different sites}

Early reports on patients with malignancy showed a raised excretion of fluorescent urinary components, which were very probably pteridines $(77,78)$. A pterin excreted by patients with cancer and by malignant cells in tissue culture media was originally tentatively identified as pterin-6-aldehyde (33), but was later identified as 6-hydroxymethylpterin (59). A contemporary investigation using the same thin layer chromatographic assay system for urine samples showed clearly that the mere presence of pterin-6-aldehyde is not diagnostic for cancer (79). : ।

A clinical study by Wachter and coworkêrs (43) first revealed raised urinary neopterin levels in cancer patients. The mean neopterin value of 40 patients with various malignancies was significantly higher $(p<0.0001)$ than that of a control group of 43 healthy subjects. Further data on neopterin levels in patients suffering from various types of neoplastic diseases came from $R o k o s$ et al. ( 50 patients (45); 75 patients (66)) and gave similar results.

More recently Stea et al. (65) confirmed these enhanced urinary mean neopterin levels in 20 patients with advanced cancer, of which the majority had recurrent metastatic disease. In addition, these authors examined the excretion of seven unconjugated pteridines and showed a significant increase of mean xanthopterin and pterin as well as a significant decrease of isoxanthopterin when compared to a control group of 27 healthy subjects.

\section{Studies in homogeneous groups of neoplasias}

The studies reviewed above indicated clearly that urinary neopterin elevations occur in a wide variety of malignant diseases. Therefore, subsequent investigations should be directed towards more homogeneous groups of neoplasias. The clinical significance of the neopterin estimation in cancer diagnosis, in the staging of disease and in monitoring cancer treatment requires detailed studies.

Urinary neopterin levels and correlations to clinical features, to tumour staging and to laboratory data have been described in haematological neoplasias $(49,76)$. Results obtained from 216 patients with haematological neoplasias are shown in table 4 . All patients with malig. nancies in an active state $(n=135)$ revealed significantly $(p<0.0005)$ elevated mean values when compared to the sex-and agepaired control group. The patients with multiple myeloma stage $I$ in which the mean value was raised only moderately and almost coincided with the upper normal limit were exceptions. The total frequency of elevated neopterin levels for patients in an active state was $114 / 135(84 \%)$.

On the other hand, the mean values of 56 patients with neoplasias in remission and of 25 patients with benign haematological diseases were below the upper normal limit. Only $7 / 56(12.5 \%)$ of patients with neoplasias in remission and $4 / 25(16 \%)$ of patients with benign diseases were in the pathological range. It is interesting to note that neoplastic proliferations such as multiple myeloma and polycythaemia vera, which represent prototypes of well-differentiated tumours, exhibited only moderately increased mean values. In contrast, 
high mean values were shown in poorly differentiated chronic lymphoid leukaemia and in non-Hodgkin's lymphoma occurring in both poorly and well-differenti:ated forms.

In patients with chronic lymphocytic leukaemia and with non-Hodgkin's lymphoma the urinary neopterin levels correlated with the stage of disease (76). The mean neopterin values in stages I and II were significantly raised compared to the control group. The highest mean values were observed in patients with stages III and IV and with large tumour burdens.

In patients with chronic leukaemias the urinary neopterin excretion correlated with occurrence of hepatosplenomegalia and with haematological criterias such as serum levels of leukocytes, platelets and haemoglobin.

Tab. 4. Urinary neopterin levels ( $\mu \mathrm{mol}$ neopterin per mol creatinine) and frequency of values exceeding the upper limits of normal in patients with haematological neoplasias, ${ }^{*}$ ) haemolytic anaemia and benign paraproteinaemia.

*) Data from Hausen et al. (49)

**) Upper limits tested according to Liebermann (70) containing with $95 \%$ probability $97.5 \%$ of healthy subjects.

\begin{tabular}{|c|c|c|c|c|}
\hline Diagnosis & $\begin{array}{l}\text { No. } \\
\text { of } \\
\text { sub- } \\
\text { jects }\end{array}$ & $\overline{\mathbf{x}} \pm S D$ & $\begin{array}{l}\text { Above } \\
\text { the } \\
\text { upper } \\
\text { lim- } \\
\text { it**) }\end{array}$ & $\begin{array}{l}\% \text { in the } \\
\text { patho- } \\
\text { logical } \\
\text { range }\end{array}$ \\
\hline $\begin{array}{l}\text { Haemolytic } \\
\text { anaemia }\end{array}$ & 16 & $178 \pm 80$ & 3 & 19 \\
\hline $\begin{array}{l}\text { Benign para- } \\
\text { proteinaemia }\end{array}$ & 9 & $167 \pm 58$ & 1 & 11 \\
\hline $\begin{array}{l}\text { Polycythaemia } \\
\text { vera }\end{array}$ & 12 & $363 \pm 183$ & 9 & 75 \\
\hline $\begin{array}{l}\text { Multiple myelomą, } \\
\text { stage I }\end{array}$ & 7 & $249 \pm 183$ & 2 & 29 \\
\hline $\begin{array}{l}\text { Multiple myeloma, } \\
\text { stage II, III }\end{array}$ & 20 & $384 \pm 183$ & 14 & 70 \\
\hline $\begin{array}{l}\text { Multiple myeloma, } \\
\text { remission }\end{array}$ & 7 & $147 \pm 39$ & 0 & 0 \\
\hline $\begin{array}{l}\text { Hodgkin's } \\
\text { lymphoma }\end{array}$ & 16 & $347 \pm 130$ & 14 & 88 \\
\hline $\begin{array}{l}\text { Hodgkin's } \\
\text { lymphoma, } \\
\text { remission }\end{array}$ & 24 & $231 \pm 96$ & 5 & 21 \\
\hline $\begin{array}{l}\text { Aoute leukaemia, } \\
\text { remission }\end{array}$ & 12 & $145 \pm 63$ & -1 & 8 \\
\hline $\begin{array}{l}\text { Chronic myelocytic } \\
\text { leukaemia }\end{array}$ & 21 & $552 \pm 317$ & 20 & 95 \\
\hline $\begin{array}{l}\text { Chronic } \\
\text { lymphocytic } \\
\text { leukaemia }\end{array}$ & 26 & $612 \pm 266$ & 25 & 96 \\
\hline $\begin{array}{l}\text { Non-Hodgkin's } \\
\text { lymphoma }\end{array}$ & 33 & $\begin{array}{c}710 \pm 440 \\
\cdot\end{array}$ & 30 & 91 \\
\hline $\begin{array}{l}\text { Non-Hodgkin's } \\
\text { lymphoma, } \\
\text { remission }\end{array}$ & 13 & $193 \pm 70$ & 1 & 8 \\
\hline
\end{tabular}

These data suggest that the urinary neopterin assay can advantageously supply clinical and laboratory parameters to assess the extent, progression and outcome in haematological neoplasias.

The clinical utility of the urinary neopterin measurement was improved in patients with gynaecological tumours (69). There was a significant difference $(p<0.01)$ between the mean values of 63 untreated tumour patients and 96 healthy women compared in each case to the age-paired group. Table 5 shows the clinical significance of the urinary neopterin estimation. Of patients examined at the onset of therapy, 41/63 $(65 \%)$ exhibited neopterin levels above the upper normal limit.

Tab. 5. Distribution of urinary neopterin levels in patients with gynaecological tumours prior to beginning of therapy and in follow up treatment.*

*) Data from Bichler et al. (69)

**) Upper limits tested according to Liebermann (70) containing with $95 \%$ probability $90 \%$ of healthy women.

\begin{tabular}{|c|c|c|c|c|c|}
\hline & \multicolumn{2}{|c|}{$\begin{array}{l}\text { Prior } \\
\text { to beginning } \\
\text { of therapy }\end{array}$} & \multicolumn{3}{|c|}{ Follow-up treatment } \\
\hline & $\begin{array}{l}\text { No } \\
\text { of } \\
\text { sub- } \\
\text { jects }\end{array}$ & $\begin{array}{l}\text { Above } \\
\text { the } \\
\text { upper } \\
\text { lim- } \\
\text { it**) }^{* *}\end{array}$ & $\begin{array}{l}\text { No } \\
\text { of } \\
\text { sub- } \\
\text { jects }\end{array}$ & $\begin{array}{l}\text { Corre- } \\
\text { spond- } \\
\text { ence to } \\
\text { clinical } \\
\text { and } \\
\text { X-ray } \\
\text { findings }\end{array}$ & $\begin{array}{l}\% \\
\text { Corre- } \\
\text { spond- } \\
\text { ence }\end{array}$ \\
\hline Ovarian cancer & 8 & 7 & 26 & 21 & 81 \\
\hline Cervical cancer & 39 & 23 & 36 & 27 & 75 \\
\hline $\begin{array}{l}\text { Endometrial } \\
\text { cancer }\end{array}$ & 13 & 9 & 10 & 5 & 50 \\
\hline $\begin{array}{l}\text { Cancer } \\
\text { of the vulva }\end{array}$ & 3 & 2 & & & \\
\hline Total & 63 & $\begin{array}{l}41 \\
(65 \%)\end{array}$ & 72 & 53 & 74 \\
\hline
\end{tabular}

It is noticeable that in follow-up treatment in patients with gynaecological malignancies the neopterin assay provides even better results. In 53/72 (74\%) patients the clinical and $\mathrm{X}$-ray findings corresponded well with the urinary neopterin levels.

Both reports $(49,69)$ suggest a potential usefulness of the urinary neopterin measurement in the assessment of haematologic neoplasias and of gynaecologic tumours. A clinical applicability of the neopterin assay in these malignancies appears likely.

\section{Comparison of the urinary neopterin assay with other tumour markers}

The initial burst of enthusiasm in the field of tumour markers has greatly disappeared during the past several 
years, and this field has been the subject of considerable questioning $(80,81)$. Problems involved in this area may partly be caused by methodic difficulties which lead to inconsistent results. Often somewhat low upper normal limits were stated no doubt producing high frequency of elevated levels in carcinoma patients and also in patients with benign diseases and in healthy subjects. Thus, the lack of true cancer specificity is seen as the main drawback of the known tumour marker substances.

To date, more rational studies have been undertaken to evaluate the role of tumour markers. Extensive clinical investigations have revealed that the value of tumour markers does not necessarily lie in their use for cancer screening and for early diagnosis $(82,83,84)$; a considerable amount of pertinent data indicate that tumour markers help in prognosis and in monitoring cancer treatment as an adjunctive tool for the clinical and physical examination $(85,86,87)$.

Urinary neopterin seems to be a sensitive marker compared with the best established biochemical markers, such as polyamines for haematologic (96) and carcinoembryonic antigen for gynaecologic tumours (97). Such a comparison would require measurement of all three markers concurrently in a study of the same patients. At present, only results of different authors are available. The problems inherent when comparing such results are the clinical examination and the considerable difference of the upper normal limits used. This variability in the upper normal limits seems to limit the usefulness of the CEA assay as a tumour marker at the present time. For the reasons stated, the occurrence of elevated levels of the three markers shown in table 6 has to be interpreted with caution.
However, in table 6 there is some evidence that the sensitivity of the urinary neopterin assay is at least comparable with that of polyamine sampling for haematologic neoplasias. The polyamines as tumour associated markers require determination of three components (putrescine, spermidine and spermine). Therefore we believe that the neopterin technique is superior to the polyamines method with respect to rapidity and applicability to routine analysis. Apart from this methodic aspect, the biological mechanism involved in the excretion of neopterin differs distinctly from that of polyamines. No statistically significant difference of neopterin levels between treated and untreated patients was observed (49). In contrast, a correlation between increase of spermine and spermidine with cell death due to treatment has been reported (98).

In table 6, the neopterin assay is compared to the CEA assay as the best biochemical marker for carcinomas of the female genital tract at the present time. It has to be noted that the neopterin estimation is not inferior with respect to sensitivity. Most diagnostic difficulties of carcinomas in the female genital tract are encountered in carcinoma of the ovary. In contrast to the CEA results the incidence of neopterin elevations was found to be particularly high for this type of carcinoma. Therefore, the determination of urinary neopterin levels in addition to the X-ray and clinical findings would be of benifit for the clinician in the management of ovarian cancer.

At present, prospective studies on the clinical applications of neopterin levels have still not been performed. We emphasize that neopterin elevations àssociated with tumours were first described in 1979 (43). CEA was proposed as a tumour marker by Gold \& Freedman in 1965 (99) and polyamines by $R$ ussel in 1971 (100).

Tab. 6. Comparison of different tumour markers in patients with haematological neoplasias and with tumours of the female genital tract. $\%=$ incidence of elevated levels in $\% \quad(n)=$ number of patients investigated

\begin{tabular}{|c|c|c|c|c|c|c|c|c|c|}
\hline \multirow[b]{2}{*}{ Diagnosis } & \multicolumn{2}{|c|}{ Neopterin } & \multirow[b]{2}{*}{ Authors } & \multicolumn{3}{|c|}{ CEA } & \multicolumn{3}{|c|}{ Polyamines } \\
\hline & $\%$ & (n) & & $\%$ & (n) & Authoris & & (n) & Authors \\
\hline Polycythaemia vera & 75 & 12 & (49) & & & & 64 & 11 & $(88)$ \\
\hline Multiple myeloma & 59 & 27 & (49) & & & & & & \\
\hline Hodgkin's lymphoma & 88 & 16 & (49) । & & & & $60-100$ & 11 & $(90)$ \\
\hline Non-Hodgkin's lymphoma & 91 & 33 & (49) & 35 & 72 & (89) & $55=68$ & 38 & (90) \\
\hline $\begin{array}{l}\text { Chronic myelocytic } \\
\text { leukaemia }\end{array}$ & 95 & 21 & (49) & & & & $\mathbf{7 8}$ & 123 & . (90) \\
\hline $\begin{array}{l}\text { Chronic lymphocytic } \\
\text { leukaemia }\end{array}$ & 96 & 26 & (49) & 38 & 40 & (89) & & & \\
\hline Carcinoma of ovary & 88 & 8 & (69) & $\begin{array}{l}45 \\
21 \\
19 \\
17\end{array}$ & $\begin{array}{r}11 \\
53 \\
140 \\
30\end{array}$ & $\begin{array}{l}(91) \\
(92) \\
(93) \\
(94)\end{array}$ & & & \\
\hline Carcinoma of cervix & 59 & 39 & (69) & $\begin{array}{l}40 \\
34 \\
30 \\
43\end{array}$ & $\begin{array}{l}40 \\
97 \\
54 \\
88\end{array}$ & $\begin{array}{l}(91) \\
(93) \\
(94) \\
(95)\end{array}$ & & i & \\
\hline $\begin{array}{l}\text { Carcinoma } \\
\text { of endometrium }\end{array}$ & 69 & 13 & $(69)$ & 20 & 10 & (92) & & & \\
\hline
\end{tabular}


Since the neopterin assay is still at an early stage of development its biological role remains open. Results presented in table 4 and 5 indicate that high mean urinary neopterin levels and a high incidence of elevations occur particularly in undifferentiated neoplasias. The lowest occurrence of elevated levels obtained in patients with carcinoma of the cervix appears to reflect a poor clinical correlation of urinary neopterin levels. in well differentiated solid tumours of epithelial origin. Current experiments with mixed lymphocyte cultures (unpublished) explain that the neopterin excretion is associated with activation of T-lymphocytes. As already supposed (76) elevated neopterin levels seem to represent end products of a host response - the cell mediated immunity - against the tumour. This hypothesis is consistent with the high neopterin levels observed in patients with viral infection (43) which activates T-lymphocytes.

\section{Conclusions}

HPLC on reversed phase enables the determination of urinary pteridines with satisfactory sensitivity, accuracy and practicability, as is necessary for tumour markers in routine clinical laboratory use.

In this survey, an association was indicated between enhanced or dedifferentiated proliferation and release of pteridines into cell culture media or urine. Further, high pteridine contents in rapidly growing tissues were demonstrated.

There are several reports that have confirmed raised neopterin levels in patients with malignancies in advanced disease of various types.

For the clinical utility of the neopterin assay it is advantageous that neopterin levels above the upper normal limit rarely occur in healthy adults or in patients with benign diseases and occur only in a low percentage of patients with neoplasias in remission.

The urinary neopterin assay has been tested in detail for two homogeneous groups of malignancies, namely haematological and gynaecological neoplasias. Correlations to clinical staging, to well established clinical features and laboratory data have been shown. Furthermore, it appears that the neopterin determination aids the monitoring of therapy in cancer patients.

The frequency of urinary neopterin elevations was compared with literature data of polyamines as markers for haematologic, and of CEA as marker for gynaecologic neoplasias. The urinary neopterin assay is at least comparable to these assays.

In summary, the results of the urinary neopterin measurement are encouraging. Further exploration of the clinical application should be pursued particularly in poorly differentiated neoplasias of non epithelial origin.

\section{References}

1. Rembold, H. (1972) Angew. Chem. 84, 1088-1099.

2. Pfleiderer, W. (1963) Angew. Chem. 75, 993-1040.

3. Pfleiderer, W. (ed.) (1975) Chemistry and Biology of Pteridines, de Gruyter, Berlin.

4. Kisliuk, R. L. \& Brown, G. M. (eds.) Chemistry and Biology of Pteridines, (1978) Elsevier/North Holland, New York.

5. Albert, A. (1975) in 1.c. (3), 1-26.

6. Lund, H. (1975) in 1.c. (3), 645-670.

7. Scrimgeour; K. G. (1975) in 1.c. (3), 731-751.

8. Pearson, A. J. \& Blair, J. A. (1975) in 1.c. (3), 775-781

9. Rokos, K. \& Pfleiderer, W. (1975) in l.c. (3), 931-939.

10. Baur, R., Kappel, M., Mengel, R. \& Pfleiderer, W. (1978) in 1.c. (4), 13-18.

11. Fukushima, T. \& Nixon, J. C. (1978) in 1.c. (4), 31-34.

12. Pfleiderer, W. (1978) in 1.c. (4), 63-69.

13. Kaufman, S. (1967) Ann. Rev. Biochem. 36, 171-184.

14. Kaufman, S. (1975) in 1.c. (3), 291-304.

15. Tietz, A., Lindberg, M. \& Kennedy, E: P. (1964) J. Biol. Chem. 239, 4081-4090.

16. Fuller, R. C. \& Nugent, N. A. (1969) Proc. Natl. Acad. Sci. $63,1311-1318$.

17. Iwai, K., Kobashi, M., Suzuki, T. \& Bunno, M. (1978) in l.c. (4), 111-116.

18. Cremer-Bartels, G. \& Ebels, İ. (1980) Proc. Natl. Acad. Sci. 77, 2415-2418.

19. Forrest, H. S. (1970) in "Chemistry and Biology of Pteridines" (Iwai, K., Goto, M., Akino, M. \& Iwanami, X., eds.), 155-162, Int. Acad. Printing Co, Tokyo.

20. Kraut, H., Pabst, W., Rembold, H. \& Wildemann, L. (1963) Hoppe-Seyler's Z. Physiol. Chem. 332, $101-108$.

21. Pabst, W. \& Rembold, H. (1966) Hoppe-Seyler's Z. Physiol. Chem. 344, 107-112.
22. Brenner-Holzach, O. \& Leuthardt, F. (1967) Hoppe Seyler's Z. Physiol. Chem. 348, 605-606.

23. Weygand, F., Simon, H., Dahms, G., Waldschmidt, M., Schliep, H. J. \& Wacker, H. (1961) Angew. Chem. 73, 402-407.

24. Watt, W. B. (1967) J. Biol. Chem. 242, 505-572.

25. Jones, T. H. D. \& Brown, G. M. (1967) J. Biol. Chem. 242, 3989-3997.

26. Plowman, J., Cone, J. E. \& Guroff, G. (1974) J. Biol. Chem. $249,5559-5564$.

27. Fukushima, T. (1970) Arch. Biochem. 139, 361-369.

28. Brown, G. M., Krivi, G. G., Fan, C. L. \& Unnasch, T. R. (1978) in l.c. (4), 81-86.

29. Eto, J., Fukushima, K. \& Shiota, T. (1976) J. Biol. Chem. $251,6505-6512$.

30. Rembold, H. (1970) in "Chemistry and Biology of Pteridines" (Iwai, K., Goto, M., Akino, M. \& Iwanami, Y. eds.), 163-178, Int. Acad. Printing Co, Tokyo.

31. Guttman, H. N. (1964) in "Pteridine Chemistry" (Pfleiderer, W. \& Taylor, E. C., eds.), 255-266, Pergamon press, Oxford.

32. Ziegler, I. (1960) Z. Naturforsch. 15b, 460-465.

33. Halpern, R., Halpern, B. C., Stea, B., Dunlap, A., Conklin, K., Clark, B., Ashe, H., Sperling, L., Halpern, J. A., Hardy, D. \& Smith, R. A. (1977) Proc. Natl. Acad. Sci. 74, 587591.

34. Schlesinger, P., Watson, B. M., Cotton, R. G. H. \& Danks, D. M. (1979) Clin. Chim. Acta 92, 187-195.

35. Gantner, G., Graßmayr, K., Hausen, A. \& Wachter, H. (1977) Mikrochim. Acta 2, 33-38.

36. Wachter, H., Graßmayr, K. \& Hausen, A. (1979) Cancer Lett. $6,61-66$. 
37. Rembold, H. \& Buschmann, L. C. (1964) in "Pteridine Chemistry" (Pfleiderer, W. \& Taylor, E. C., eds.), 243-254, Pergamon Press, Oxford.

38. Sakurai, A. S. \& Goto, M. (1967) J. Biochem. 61, 142-145.

39. Bailey, S. W. \& Ayling. J. E. (1975) in 1.c. (3), 633-643.

40. Stea, B., Halpern, R. M. \& Smith, R. A. (1979) J. Chromatogr. $168,385-393$.

41. Stea, B., Halpern, R. M., Halpern, B. C. \& Smith, R. A (1980) J. Chromatogr. 188, 363-375.

42. Dhondt, J. L., Largilliere, C., Ardouin, P., Farriaux, J. P. \& Dautrevaux, M. (1981) Clin. Chim. Acta 110, 205-214.

43. Wachter, H., Hausen, A. \& Graßmayr, K. (1979) HoppeSeyler's Z. Physiol. Chem. 360, 1957-1960.

44. Fukushima, T. \& Nixon, J. C. (1978) in 1.c. (4), 35-36.

45. Rokos, H., Rokos, K., Frisius, H. \& Kirstaedter, J. H. (1980) Clin. Chim. Acta 105, 275-286.

46. Niederwieser, A., Matasović, A., Curtius, H. C., Endres, W. \& Schaub, J. (1980) FEBS Letters 118, 299-302.

47. Hausen, A., Fuchs, D., König, K. \& Wachter, H. (1982) J. Chromatogr. 227, 61-70.

48. Hausen, A., Fuchs, D. \& Wachter, H. (1981) J. Clin. Chem. Clin. Biochem. 19, 375-378.

49. Hausen, A., Fuchs, D., Grünewald, K., Huber, H., König, K. \& Wachter, H. (1982) Clin. Biochem. 15, 34-37.

50. Röthler, F. \& Karobath, M. (1976) Clin. Chim. Acta 69, 457-462.

51. Nagatsu, T., Yamaguchi, T., Kato, T., Sugimoto, T., Matsuura, S., Akino, M., Tsuchima, S., Nakazawa, N. \& Ogawa, H. (1981) Anal. Biochem. 110, 182-189.

52. Fukushima, T. \& Nixon, J. C. (1980) Anal. Biochem. 102 $176-188$

53. Wachter, H., Hausen, A., Reider, E. \& Schweiger, M. (1980) Naturwissenschaften $67,610-611$.

54. Kokolis, N. \& Ziegler, I. (1968) Z. Naturforsch. 23b, 860865

55. Kokolis, N., Mylonas, N. \& Ziegler, I. (1972) Z. Naturforsch. 27b, 285-291.

56. Kokolis, N., Mylonas, N. \& Ziegler, I. (1972) Z. Naturforsch. $27 b, 292-295$.

57. Kokolis, N. \& Ziegler, I. (1977) Cancer Biochem. Biophys. $2,79-85$.

58. Albrecht, A. M., Biedler, J., Baker, H., Frank, O. \& Hutner, S. H. (1978) Res. Commun. Chem. Pathol. Pharmacol. 19, $377-380$.

59. Stea, B., Backlund, P. S., Berkey, P. B., Cho, A. K., Halpern, B. C., Halpern, R. M: \& Smith, R. A. (1978) Cancer Res. 38, 2378-2384.

60. Rembold, H. \& Buschmann, L. (1963) Chem. Ber. 96, 14061410.

61. Fukushima, T. \& Shiota, T. (1972) J. Biol. Chem. 247, 4549-4556.

62. Fukushima, T., Kobayashi, K. I., Eto, I. \& Shiota, T. (1978) Anal. Biochem. 89, 71-79.

63. Leeming, R. L., Blair, J. A., Mellikian, V. \& O’Gorman, D. J. (1976) J. Clin. Pathol. 29, 444-451.

64. Niederwieser, A., Curtius, H. C., Gitzelmann, R., Otten, A., Baerlocher, K., Blehova, B., Berlow, S., Grobe, H., Rey, F., Schaub, J., Scheibenreiter, S., Schmidt, H. \& Viscontini, M. (1980) Helv. Paediat. Acta 35, 335-342.

65. Stea, B., Halpern, R. M., Halpern, B. C. \& Smith, R. A. (1981) Clin. Chim. Acta 113, 231-242.

66. Rokos, K., Frisius, H., Kirstaedter, H. J., Fleige, H. E. John, F. \& Rokos, H. (1981) in "CEA und andere Tumormarker" (Uhlenbruck, G. \& Wintzer, G., eds.), 408-412, Tumor Diagnostik Verlag, Leonberg.
67. Dhondt, J. L., Ardouin, P., Hayte, J. M. \& Farriaux, J. P. (1981) Clin. Chim. Acta 116, 143-162.

68. Nagatsu, T., Yamaguchi, T., Kato, T., Sugimoto, T., Matsuura, S., Akino, M., Nagatsu, I., lizuka, R. \& Narabayashi, H. (1981) Clin. Chim. Acta 109, 305-311.

69. Bichler, A., Fuchs, D., Hausen, A., Hetzel, H., König; K. \& Wachter, H. (1982) Clin. Biochem. 15, 38-40.

70. Sachs, L. (1978) „Angewandte Statistik“", 221 -222, Springer Verlag, Berlin, Heidelberg, New York.

71. Danks, D. M., Bartholomée, K., Clayton, B. E.; Curtius, H., Gröbe, H., Kaufman, S., Leeming, R., Pfleiderer, W., Rembold, H. \& Rey, F. (1978) J. Inher. Metab. Dis. 1, 49-53.

72. Watson, B. M., Schlesinger, P. \& Cotton, R. G. H. (1977) Clin. Chim. Acta 78, 417-423.

73. Watson, B. M., Armarego, W. L. F., Schlesinger, P., Cotton, R. G. H. \& Danks, D. M. (1978) in 1.c. (4), 159-164.

74. Curtius, H. Ch., Niederwiesèr, A., Viscontini, M., Otten, A., Schaub, J., Scheibenieither, S. \& Schmidt, H. (1979) Clin. Chim. Acta 93, 251-262.

75. Niederwieser, A., Curtius, $\mathrm{H}_{\text {: }} \mathrm{Ch}_{\text {.; }}$ Bettoni, O., Bieri, J., Schirks, B. \& Viscontini, M. (1979) Lancet $I$, 131-133

76. Hausen, A., Fuchs, D., Grïnewald, K., Huber, H., König, K. \& Wachter, H. (1981) Clin. Chim. Acta 117, 297-305.

77. Wachter, H., Graßmayr, K., Gütter, W., Hauseñ, A., Sallaberger, G. \& Gabl, F. (1971) Brit. Med. J. 2, 322-323.

78. Wachter, H., Graßmayr, K., Gütter, W., Hausen, A. \& Salla berger, G. (1972) Wien. Klin. Wochenschr. 84, 586-590.

79. Dinovo, E. C., Lynn, J. K., McIntosh, M. E. \& Johnson, M. (1978) Clin. Chem. 24, 1002.

80. Kleist, von S. U. (1980) Cancer Res. 40, 2977-297.8.

81. Tate, H. (1981) Br. J. Cancer 44, 643-651.

82. Martin, E. W., Kibbey, W. E., Di Vecchia, L., Anderson, G. Catalano, P. \& Minton, J. P. (1976) Cancer 37, 62-81.

83. DiŚaia, P. J. (1976) Cancer 38, 566-580.

84. Lokich, J. J. (1978) Oncology 35, 54-57.

85. Gold, P. \& Shuster, J. (1980) Cancer Res. 40, 2973-2976.

86. Goldenberg, D. M., Kim, E. E., De Land, F. H., Bennett, S \& Primus, F. J. (1980) Cancer Res. 40, 2984-2992.

87. National Institutes of Health Consensus Development Conference Statement. 1981, Cancer Res. 41, 2017-2018.

88. Desser, H., Höcker, P., Weiser, M. \& Böhnel, J. (1975) Clin. Chim. Acta 63, 243-247.

89. Roche Collaborative Study. Data on file, F. Hofmann-La Roche \& Co. A.G., Basel.

90. Desser, H. (1981) Ber. ÖGKC 4, 251-253.

91. Nagell, J. R., Meeker, W. R., Parker, J. C. \& Harralson, J. D. (1975) Cancer 35, 1372-1376.

92. Seppälä, M., Pihko, H. \& Ruoslahti, E. (1975) Cancer 35 $1377-1381$

93. Malkin, A., Kellen, J. A., Lickrish, G. M. \& Bush, R. S. (1978) Cancer 42, $1452-1456$.

94. Cauchi, M. N., Koh, S. H., Lim, D. \& Hay, D. L. (1981) Br J. Cancer 44, 403-409.

95. Braun, P., Hildenbrand, G., Izbicki, J. \& Leyendecker, G. (1981) Arch. Gynecol. 230, 263-273.

96. Russell, D. H. (1977) Clin. Chem. 23, 22-27.

97. Neville, A. M. (1980) Arch. Gynecol. 229, 311-323.

98. Niskioka, K., Ezaki, K. \& Hart, J. (1980) Clin. Chim. Acta $107,59-66$.

99. Gold, P. \& Freedman, S. O. (1965) J. Exp. Med. 122, 467481.

100. Russell, D. H. (1971) Nature $223,144-145$.

Doz. Dr. Arno Hausen

Prof. Dr. Helmut Wachter Institut für Medizinische Chemie und Biochemie der Üniversität İnnsbruck Fritz-Pregl-Straße 3 A-6020 Innsbruck, Österreich 